\title{
ВИЗНАЧЕННЯ ІНСТРУМЕНТАРІЮ ДІАГНОСТУВАННЯ ГОТОВНОСТІ ОФІЦЕРІВ ДО ЗДІЙСНЕННЯ МОВНОЇ ПІДГОТОВКИ У ВІЙСЬКОВИХ ЧАСТИНАХ НАЦІОНАЛЬНОЇ ГВАРДІЇ УКРАЇНИ
}

\begin{abstract}
Анотація. Для ефективного визначення офіцерів-викладачів (інструкторів) готових до здійснення мовної підготовки у військових частинах Національної гвардії України, обтрунтовання дієвого інструментарію формування готовності офіцерів до здійснення мовної підготовки проведено аналіз та визначенно рівні готовності (високий, середній, низький), критерії готовності офіцерів до здійснення мовної підготовки та відповідні їм показники: для мотиваційного критерію - професійна стійкість, професійні інтереси, професійні наміри; для пізнавального - здатність до аналізу військово-педагогічної діяльності, здатність до самоаналізу, рівень оволодіння іноземною мовою за стандартами HATO STANAG 6001 2+/2+/2+/2+; для результативного - здатність накопичення й усвідомлення здобувачами досвіду участі в реальному освітньому процесі, здатність передачі накопичених знань та практичного досвіду в процесі здійснення мовної підготовки. Здатність організовувати освітній процес. Визначений інструментарій діагностування готовності офріцерів до здійснення мовної підготовки у військових частинах Національної гвардії України. Він бу розроблений спираючись на такі роботи: «Сенсожиттевої орієнтації» (С. Мадді), «Методика вивчення мотиваційного профілю особистості» (Ш. Річі та П. Мартін), адаптований опитувальник Е. Зеера «Професійні наміри», «Прогресивні матриці Равена», «Мотивація успіху і острах невдачі» (А.А. Равен), вихідне тестування за стандартами HATO STANAG 6001, результати контролю навчальних досягнень за підсумками періоду навчань: проведення відкритих занять, екзамен після закінчення навчання за програмою підвищення кваліфікації не нижче 90 за 100 бальною системою.
\end{abstract}

Ключові слова: готовність офіцерів, мовна підготовка, рівні готовності, критерії готовності, показники готовності, інструментарій діагностування готовності.

Honchar Volodymyr

National Academy of the National Guard of Ukraine

\section{DEFINITION OF PREPAREDNESS DIAGNOSTIC TOOLS OF OFFICERS FOR LANGUAGE TRAINING IN THE MILITARY UNITS OF THE NATIONAL GUARD OF UKRAINE}

Summary. In order to effectively determine the officers-tutors can be ready for language training in the military units of the National Guard of Ukraine, to substantiate the effective tools for forming the readiness of officers for language training, the analysis of readiness and high levels of readiness: (high, medium, low), the criteria of officers' readiness for language training and its indicators: for the motivational criterion - professional stability, professional interests, professional intentions; for cognitive - the ability to analyze military-pedagogical activities, the ability for self-analysis, the level of foreign language proficiency according to NATO standards STANAG $60012+/ 2+/ 2+/ 2+$; for effective - the ability to accumulate and understand the experience of participants in the real educational process, the ability to transfer the accumulated knowledge and practical experience in the process of language training. Grades for classes - "passed" or "not passed", the ability to organize the educational process. The diagnosed tools of officers' readiness for the language training in the military units of the National Guard of Ukraine are defined: "Sense-life orientation" (S. Muddy translation and adaptation by D. Leontiev, E.I. Rasskazova), "Methods of studying the motivational profile of personality" Sh. Richi, P. Martin), adapted E. Zeer's questionnaire "Professional intentions", "Raven's progressive matrices", "Motivation for success and fear of failure" (A.A. Raven), initial testing according to NATO standards STANAG 6001, results of monitoring academic achievements by the end of the training: presentation of intro class, binary classes. Exam after graduation from the advanced training program not less than 90 per 100 points system. The article offers a table of components for testing the officers' readiness for language training in the military units of the National Guard of Ukraine. It is also proposed to classify the motives which can be reasons to choose educational activities during the military service. Further research into the chosen problems looks promising and the content-functional model of forming the officers' readiness for language training in the military units of the National Guard of Ukraine will be substantiated in our forthcoming research.

Keywords: readiness of officers, language training, readiness levels, readiness criteria, readiness indicators, readiness diagnostics tools.

$\Pi$ остановка проблеми. Враховуючи потреби Національної гвардії України (далі - НГУ) у переході на стандарти передових країн та досягнення взаємосумісництва, збільшення кількості заходів співробітництва з підрозділами країн-членів НАТО є необхідність у внесенні корективів до існуючої системи профре- сійної підготовки військовослужбовців НГУ. Потреба вдосконалення діючої системи професійної підготовки військовослужбовців НГУ пояснюється подальшим внесенням до переліку предметів, що виносяться на профресійну підготовку офріцерів, іноземної мови. Впровадження занять з іноземної мови має надати можливість всьому

\footnotetext{
${ }^{1}$ ORCID: https://orcid.org/0000-0001-9426-2180
} 
особовому складу займатися без відриву від основного місця служби та сягнути відповідних рівнів володіння іноземною мовою, в залежності від займаних посад. Завдання з швидкого оволодіння необхідними рівнями іноземної мови зазначених категорій та процес збереження навичок на належному рівні в подальшому можливо виконати за умови одночасного проведення занять 3 іноземної мови в територіальних об'єднаннях, частинах прямого підпорядкування та навчальних закладах НГУ. В свою чергу це не можливо зробити без підготовлених офіцерів-викладачів (інструкторів) іноземної мови, які розуміють специфіку виконання завдань НГУ, є підготовленими із урахуванням досвіду застосування НГУ як під час виконання завдань за призначенням, так і у заходах міжнародного співробітництва.

Залучення цивільних викладачів або направлення особового складу на курси іноземних мов до інших закладів освіти чи приватних курсів вимагає: додаткових витрат з бюджету, відриву особового складу від основного місця роботи та, найголовніше, збільшуе витрати часу. Також потрібно враховувати, що освітні програми інших закладів освіти, які направленні на вивчення іноземних мов, не враховують специфіки виконання завдань НГУ. Саме тому слід звернути увагу на підготовку офіцерів-викладачів (інструкторів) іноземної мови в НГУ.

Наразі на укомплектування таких кадрів впливає відсутність введених посад викладачів (інструкторів) іноземної мови у військових частинах. Труднощі реалізації якісної мовної підготовки у військових частинах спричинені як відсутністю належних нормативно-правових актів з організації індивідуальної підготовки офріцерів, так і недостатніми методичними напрацюваннями відносно теоретичних і методичних засад формування готовності офіцерів до здійснення мовної підготовки у військових частинах НГУ. Серед можливих шляхів вирішення цієї проблеми $є$ навчання викладачів (інструкторів) 3 іноземної мови за спеціально розробленою програмою інтенсивних курсів 3 вивчення іноземних мов та курсів післядипломної освіти для викладачів (інструкторів). Водночас із введенням посад викладача (інструктора) з іноземної мови виникає потреба у підборі дієвого інструментарію діагностування готовності офіцерів викладачів (інструкторів) до здійснення мовної підготовки.

Аналіз останніх досліджень і публікацій. Проблемою готовності і професійної готовності до педагогічної діяльності займалися такі науковці: О. Благосмислов, І. Шелудько, Ю. Вербиненко, Н. Кавуненко, М. Коваль, М. Козяр, А. Литвин, Ю. Медвідь, С. Морозов, Г. Федак, А. Умінська. Підготовкою викладачів та вдосконаленням мовної підготовки: І. Білецька, Н. Логутіна, В. Ушмарова, А. Ушаков, М. Сотер. Специфріка викладання іноземних мов для військовослужбовців та дослідженням іншомовної підготовки: О. Артюхова, А. Вікторова, Н. Гагіна, В. Борисенко, Н. Колісніченко, К. Павелків, О. Хоменко. Специфрікою перепідготовки: А. Балендер, В. Гладка, В. Демянішин, М. Медвідь, В. Посметний, Ю. Черніченко.

Незважаючи на стійкий інтерес учених до досліджуваного напрямку, у наукових дослідженнях не враховується специфіка виконан- ня завдань НГУ та структура підрозділів НГУ, що в свою чергу впливає на впровадження нових форм освіти та стандартів країн Організацією Північно-Атлантичного договору (НАТО) у військовій сорері, неповний аналіз педагогічних умов формування готовності офріцерів до здійснення мовної підготовки у військових частинах НГУ та їх вплив на освітній процес у НГУ в цілому. Питання щодо готовності офріцерів здійснювати мовну підготовку у військових частинах не повністю досліджені, а відповідно і не copopмовано діагностичного інструментарію який би враховував всі перелічені потреби НГУ.

За результатами попередніх досліджень нами запропоновано визначення готовності офіцерів до здійснення мовної підготовки у військових частинах НГУ - «це якість, яка формується за результатом реалізації комплексу заходів профресійної готовності педагогічної діяльності, й має такі основні складники: психологічний (в тому числі наявність мотиващіі), знанневий (наявність необхідних знань), практичний (який фрормуеться на основі отриманого досвіду)» [2]. Керуючись цим визначенням готовності офріцерів до здійснення мовної підготовки у військових частинах НГУ пропонуємо виділити такі критерії: 1) мотиваційний, який забезпечуе успішність і результативність певних дій та діяльності. Це такий стан готовності, який допомагає успішно виконувати свої обов'язки, використовувати знання, досвід; 2) знанневий - система необхідних знань (компетентностей) для здійснення профресійної діяльності за напрямком діяльності; 3) результативний є формою навчання, під час якої відбувається накопичення й усвідомлення здобувачами досвіду участі в реальному освітньому процесі.

Враховуючи запропоновану нами структуру готовності в цій статті пропонуеться інструментарій 3 діагностування готовності офріцерів до здійснення мовної підготовки.

Метою статті є визначення інструментарію діагностування готовності офіцерів до здійснення мовної підготовки у військових частинах НГУ.

Виклад основного матеріалу. Передумовою визначення ефективності процесу фрормування готовності офріцерів до здійснення мовної підготовки у військових частинах НГУ є визначення рівнів, критеріїв та показників готовності офріцерів як до педагогічної діяльності, так і готовність до іншомовної підготовки, визначення інструментарію для діагностування зазначеної категоріі.

На підставі здійсненого аналізу наукової літератури, уточненого змісту поняття «готовності офіцерів до здійснення мовної підготовки у військових частинах НГУ» та визначених складників структури готовності нами було запропоновано такі рівні готовності майбутніх офріцерів до здійснення мовної підготовки такі як: високий, середній, низький.

Високий. Майбутній офіцер-викладач (інструктор) успішно засвоїв програми навчання інтенсивних курсів 3 вивчення іноземних мов та склав вихідний іспит на знання мови за STANAG 6001 не нижче 2/2/2/2.

Засвоїв програму курсів післядипломної освіти «Методика навчання іноземних мов в НГУ» [4], успішно виконав контрольні та практичні роботи за навчальною програмою та склав екзамен не 
нижче 90 балів за 100 бальною системою. Викладач (інструктор) розуміе всі труднощі майбутньої педагогічної діяльності та спроможний їх долати, оцінюе свої можливості щодо управління емоційним станом під час занять і діями на основі отримання досвіду практичних вправ та проведених практичних занять. Має сдормовані та розвинуті необхідні компетентності для педагогічної діяльності. Володіє методикою з ощінювання рівня знань іноземної мови. Чітко, упевнено, ефективно розподіляе час відведений для занять та на особисту підготовку. Оцінюе свою готовність до подолання труднощів пов'язаних 3 освітнім процесом як виклик, який можливо подолати.

Середній. Майбутній офіцер-викладач (інструктор) успішно засвоїв програми навчання інтенсивних курсів 3 вивчення іноземних мов, склав вихідний іспит на знання мови за STANAG 6001 з проміжними рівнями володіння по двом і більше навичкам $2 / 1+/ 1+/ 2$.

Засвоїв програму навчання іноземної мови курсів післядипломної освіти «Методика навчання іноземних мов в НГУ» [4], успішно виконав контрольні та практичні роботи за навчальною програмою та склав екзамен не нижче 75 балів за 100 бальною системою. Викладач (інструктор) розуміє всі труднощі майбутньої педагогічної діяльності та спроможний їх долати, ощінюе свої можливості щодо управління емощійним станом під час занять і діями на основі отримання досвіду практичних вправ та проведених практичних занять. Має не до кінця сорормовані та розвинуті необхідні компетентності для педагогічної діяльності. Посередньо володіє методикою з ощінювання іноземної мови. Потребуе вдосконалення навиків з розподілу часу відведеного для занять для оптимізації процесу засвоєння матеріалу слухачами. Оцінюе свою готовність до подолання труднощів пов'язаних з освітнім процесом як виклик, який можливо подолати.

Низький. Майбутній офріцер-викладач (інструктор) не засвоїв програми навчання інтенсивних курсів з вивчення іноземних мов, склав іспит на знання мови за STANAG 6001 нижче $1+/ 1+/ 1+/ 1+$.

Засвоїв програму навчання іноземної мови курсів післядипломної освіти «Методика навчання іноземних мов в НГУ» [4], протягом навчання не виконав всі контрольні та практичні роботи за навчальною програмою та склав екзамен нижче 60 балів за 100 бальною системою. Викладач (інструктор) не до кінця розуміе всі труднощі майбутньої військово-педагогічної діяльності та не спроможний їх долати, не може подолати свій емоційний стан під час занять. Має не до кінця сорормовані та розвинуті необхідні компетентності для педагогічної діяльності. Не володіє методикою $з$ оцінювання рівня володіння іноземною мовою. Потребує вдосконалення навиків 3 розподілу часу відведеного для занять для оптимізації процесу засвоєння матеріалу слухачами. Оцінюе свою готовність до подолання труднощів пов'язаних 3 освітнім процесом як не можливу для подолання.

Під поняттям критерї оцінки розуміють певні ознаки, на підставі яких здійснюеться оцінювання готовності, визначення або класифікація певних об'єктів, кінцевих результатів досягну- того рівня знань особистості. Розглянемо запропоновані нами критерії та ті аспекти, які вони дозволяють оцінити.

Мотиващійний критерій дозволяе ощінити внутрішній набір мотивів, які дають обгрунтованість дій, тобто сутність спонукальних чинників до розвитку інтересу до нової службової діяльності, в цьому випадку військово-педагогічної.

Пізнавальний критерій дає змогу оцінити повноту уявлень особистості про військово-педагогічну діяльності, зумовлений рівнем адекватності самооцінки особистих якостей, сформованих компетентностей.

Результативний критерій дає змогу ощінити повноту уявлень особистості про військово-педагогічну діяльності з урахуванням застосування набутих знань на практиці, можливість до саморозвитку.

Таким чином, компонентами готовності офріцерів до здійснення мовної підготовки є: мотиваційний, який оцінюеться за мотиваційним критерієм; знанневиий, який оцінюеться за пізнавальним критерієм; практичний, який оцінюється за результативним критерієм.

Показники - це докази, що характеризують ознаки певного аспекту, критерія, який відповідає компоненту готовності.

Для мотиваційного критерію показники: профресійні інтереси, професійні наміри, мотиви вибору нового напрямку військової служби.

Для пізнавального критерію показники: здатність до аналізу, здатність до самоаналізу та рівень оволодіння іноземною мовою за стандартами STANAG $2+/ 2+/ 2+/ 2+$.

Для результативного критерію показники: здатність накопичення й усвідомлення здобувачами досвіду участі в реальному освітньому процесі, здатність передачі накопичених знань та практичного досвіду в процесі здійснення мовної підготовки, здатність організовувати освітній процес.

Відповідно до визначеної структури, критерї̈, показників сформованості готовності офріцерів до здійснення мовної підготовки у військових частинах НГУ було визначено інструментарій для діагностування рівнів сформованості такої готовності (табл. 1).

Для діагностики мотивів та мотивації загалом, які спонукають до свідомого вибору освітньої діяльності під час проходження військової служби, що зумовлені рівнем оволодіння профресією, усвідомлення життя та мотивів профресійної діяльності, доцільно використовувати тест «Сенсожиттевої орієнтації» (С. Мадді) [3], де визначається: життестійкість, контроль та залученість. Так, для готового кандидата за тестом «Сенсожиттевої орієнтації»:

1) висока життестійкість - 90 і більше балів. Характеризує людину, активну і впевнену у своїх силах, таку, яка нечасто переживає стрес і здатна справлятися 3 ним, продовжуючи ефрективно працювати і не втрачати душевну рівновагу;

2) висока залученість - 42 і більше балів. Люди з високою замученістю, зазвичай, отримують задоволення від усього, що роблять, знаходять те, що їм цікаво, навіть в рутинній роботі;

3) високий контроль - 33 і більше балів. Людина 3 сильно розвиненим компонентом контролю в ситуації стресу продовжує боротьбу, не здається, 
Діагностичні методики оцінювання компонентів готовності офіцерів до здійснення мовної підготовки у військових частинах НГУ

\begin{tabular}{|c|c|c|c|}
\hline Компонент & Критерій & Показник & Діагностичні методики \\
\hline \multirow{3}{*}{ мотиваційний } & \multirow{3}{*}{ мотиваційний } & Продесійна стійкість. & \begin{tabular}{|l|} 
«Сенсожиттевої оріентації» \\
(С. Мадді) [3] \\
\end{tabular} \\
\hline & & Профресійні інтереси: & $\begin{array}{l}\text { «Методика вивчення мотиваційного } \\
\text { профілю особистості» (Ш. Річі та } \\
\text { П. Мартін) [3] }\end{array}$ \\
\hline & & Профресійні наміри & $\begin{array}{l}\text { Адаптований опитувальник } \\
\text { Е. Зеера «Професійні наміри» [3] }\end{array}$ \\
\hline \multirow{4}{*}{ знанневий } & \multirow{4}{*}{ пізнавальний } & \multirow{2}{*}{$\begin{array}{l}\text { Здатність до аналізу педагогічної } \\
\text { діяльності. }\end{array}$} & «Прогресивні матриці Равена» [3] \\
\hline & & & $\begin{array}{l}\text { «Сенсожиттєвої орієнтації» } \\
\text { (С. Мадді) [3] }\end{array}$ \\
\hline & & Здатність до самоаналізу. & $\begin{array}{l}\text { Мотивація успіху і острах невдачі } \\
\text { (А.А. Равен ) [3] }\end{array}$ \\
\hline & & $\begin{array}{l}\text { Рівень оволодіння іноземною мовою } \\
\text { за стандартами HATO STANAG } 6001 \\
2+/ 2+/ 2+/ 2+\end{array}$ & $\begin{array}{l}\text { Вихідне тестування за стандартами } \\
\text { HATO STANAG } 6001 \text { [1] }\end{array}$ \\
\hline \multirow{3}{*}{ практичний } & \multirow{3}{*}{ результативний } & $\begin{array}{l}\text { Здатність накопичення й } \\
\text { усвідомлення здобувачами досвіду } \\
\text { участі в реальному освітньому процесі. }\end{array}$ & $\begin{array}{l}\text { Результати контролю навчальних } \\
\text { досягнень за підсумками періоду } \\
\text { навчань. } \\
\end{array}$ \\
\hline & & $\begin{array}{l}\text { Здатність передачі накопичених знань } \\
\text { та практичного досвіду в процесі } \\
\text { здійснення мовної підготовки. }\end{array}$ & Проведення відкритих занять. \\
\hline & & $\begin{array}{l}\text { Здатність організовувати освітній } \\
\text { процес. }\end{array}$ & $\begin{array}{l}\text { Екзамен не нижче } 90 \\
\text { за } 100 \text { бальною системою [4] }\end{array}$ \\
\hline
\end{tabular}

шукає нові шляхи вирішення проблем. Зазвичай, такі люди відчувають, що самі обирають власну діяльність, свій шлях, вони господарі життя;

4) прийняття ризику - 16 і більше балів. Високе прийняття ризику; людина 3 високим прийняттям ризику розглядає життя як спосіб набуття досвіду і готова діяти при відсутності надійних гарантій успіху, на свій страх і ризик.

Також для діагностування мотиваційного компоненту включено методику вивчення мотиваційного профрілю особистості (Ш. Річі та П. Мартін) [3]. Комплексність такого підходу забезпечувалася б кількістю виявлених потреб, що визначають задоволеність і лояльність кожного окремого здобувача, а також ступенем ix задоволення в конкретній сдрері діяльності. Один із таких варіантів реалізації такого підходу запропонували Шейла Річі і Пітер Мартін у книзі «Управління мотиващією [3]. "Сутність мотивації вони розуміють як задоволення потреб людини в процесі праці» [3]. Опитувальником Е. Зеєра «Профресійні наміри» визначаються рівні готовності здобувача вищої освіти до професійного самовизначення щодо проходження військової служби [3].

Для діагностики знанневого компоненту пропонуються: прогресивні матриці Дж. Равена, "Сенсожиттевої орієнтащії (С. Мадді) [3]. Мотивація успіху і острах невдачі (А.А. Равен) [3] як шляхи до визанчення здатності до аналізу педагогічної діяльності та здатності до самоаналізу, розуміння труднощів майбутньої військово-педагогічної діяльності спроможності їх долати, контролювати свій емоційний стан під час занять. Також для часткового вимірювання рівня інтелектуального розвитку.

Знаннєвий компонент мовної компетентності визначається за шкалою стандартизованих мовленнєвих рівнів (далі - CMP), які відповідають рівням мовленнєвої компетенції за мовним стандартом NATO STANAG-6001.

Метою цього стандарту є надання опису рівнів володіння мовою за чотирма основними видами мовленневої діяльності. В описі надаються чіткі роз'яснення рівнів мовної компетентності згідно 3 загальноприйнятими видами мовленневої діяльності: аудіювання, говоріння, читання, письмо. В документі визначено 6 рівнів мовленнєвої компетентності від 0 до 5: Рівень 0 - Відсутність практичного вміння. Рівень 1 - Виживання. Рівень 2 - Функціональний. Рівень 3 - Продесійний. Рівень 4 - Експертний. Рівень 5 - Досконалий / рівень досвідченого носія мови.

Маємо також описи проміжних рівнів щодо кожного з аспектів мовної компетентності відповідно до стандартизованого мовленневого рівня $0+, 1+, 2+, 3+, 4+$, для покращення точності визначення рівня володіння іноземною мовою [1].

Щодо практичного компоненту, то він фрормуеться за рахунок практичної діяльності, відпрацювання на практиці усних письмових та тренувальних вправ і $є$ формою навчання. Перевіркою готовності до здійснення мовної підготовки в частині, що стосуються досвіду, то діагностичним апаратом виступає виконання контрольних робіт та тренування у проведені занять. А протягом становлення офіцера, як педагога педагогічна майстерність перевіряеться на відкритих заняттях та оцінюеться як «зараховано» або "не зараховано». Таким чином відбувається накопичення й усвідомлення досвіду участі в реальному освітньому процесі з позицій викладача.

В свою чергу програма курсів післядипломної освіти «Методика навчання іноземних мов в НГУ» розроблена 3 метою набуття та вдосконалення профресійної підготовки офіцерів викладачів (інструкторів), розвитку профресійнозначущих компетентностей офіцера викладача 
(інструктора) іноземних мов та конкурентоспроможності шляхом поглиблення i розширення профресійних знань, умінь і навичок пов'язаних 3 профресійною діяльністю. Фокус направлено на безперервний розвиток потенціалу кожного офіцера, його інтелектуального й загальнокультурного рівня, включаючи вивчення вітчизняного і зарубіжного досвіду викладання іноземних мов.

Курс створено для вдосконалення набуття та професійної підготовки офіцерів викладачів (інструкторів), поглиблення і розширення профресійних знань, умінь і навичок пов'язаних 3 професійною діяльністю, безперервного розвитку потенціалу кожного працівника, його інтелектуального й загальнокультурного рівня. Основні принципи проведення практичних занять курсів післядипломної освіти підготовки слухачів «Методика навчання іноземних мов в НГУ» відкритість до нових та неординарних ідей, толерантність, доброзичлива партнерська атмосфрера, взаєморозуміння та творчий розвиток. Слухачі мають бути відкритими до конструктивної критики. Під час навчання за програмою курсу формуються та розвиваються такі компетентностей: інтегральна компетентність (здатність розв'язувати складні задачі і практичні проблеми освітньої діяльності, в питаннях управлінської, навчальної, методичної, наукової, інноващійної, творчої та виховної роботи, що передбачає застосування теорії і методів педагогіки та психології, врахування специфріку кадрового забезпечення військових формувань та правоохоронних органів); загальні компетентності (здатність до абстрактного мислення, аналізу та синтезу; здатність планувати та управляти часом; здатність діяти соціально відповідально та свідомо; здатність приймати обгрунтовані рішення) та фрахові компетентності (здатність вірно підбирати та застосовувати методи, форми та засоби навчання іноземних мов; здатність забезпечувати позитивну динаміку навчальних досягнень здобувачів; здатність формувати та розвивати позитивний імідж офіцера викладача (інструктора)).
Формою перевірки знань за освітньою програмою курсу є тестування та підсумковий контроль, який проводиться у формі екзамену шляхом практичного заняття. Поточний контроль засвоєння знань за дисципліною здійснюеться шляхом опитування слухачів на практичних заняттях.

Висновки та перспективи подальших досліджень. За результаттами аналізу нами було визначено: рівні готовності офіцерів до здійснення мовної підготовки у військових частинах НГУ (високий, середній, низький), визначені критерії готовності офріцерів до здійснення мовної підготовки у військових частинах НГУ та відповідні їм показники (для мотиваційного критерію - профресійна стійкість, професійні інтереси, продесійні наміри, мотиви вибору педагогічної діяльності; для пізнавального - здатність до аналізу військово-педагогічної діяльності, здатність до самоаналізу, здатність організовувати освітній процес, рівень оволодіння іноземною мовою за HATO STANAG $2+/ 2+/ 2+/ 2+$; для результативного: здатність накопичення й усвідомлення здобувачами досвіду участі в реальному освітньому процесі; здатність передачі накопичених знань та практичного досвіду в процесі здійснення мовної підготовки; здатність організовувати освітній процес. Визначено інструментарій діагностування готовності офіцерів до здійснення мовної підготовки у військових частинах НГУ: «Сенсожиттевої орієнтації» (С. Мадді) [3], «Методика вивчення мотиващійного профілю особистості» (Ш. Річі та П. Мартін) [3], Адаптований опитувальник Е. Зеєра «Профресійні наміри» [3], «Прогресивні матрищі Равена» [3], Сенсожиттевої орієнтації (С. Мадді) [3], «Мотивація успіху і острах невдачі» (А.А. Равен) [3], вихідне тестування за стандартами НATO STANAG 6001 [1], результати контролю навчальних досягнень за підсумками періоду навчань. Екзамен по завершенню курсівне нижче 90 за 100 бальною системою [4].

В подальшому плануеться обгрунтовувати змістово-фрункціональну модель формування готовності офіцерів до здійснення мовної підготовки у військових частинах НГУ.

\section{Список літератури:}

1. STANAG 6001 (5-е видання) NATO Standardization office. Brussels, 2014. 56 p.

2. Гончар В.В. Визначення сутності готовності офіцерів до здійснення мовної підготовки у військових частинах Національної гвардії України. Вісник Луганського національного університету іл. Тараса Шевченка. 2021. № 1(339). Ч. I. C. 91-104.

3. Мацегора Я.В., Приходько I.І., Воробйова І.В., Горелишев С.А., Каз'яніна Н.А. Психологічний моніторинг професійно важливих якостей курсантів ВВНЗ МВС України : монографія. Харків : Акад. ВВ МВС України, 2013. $421 \mathrm{c}$.

4. Освітньо-продесійна програма підготовки слухачів курсів післядипломної освіти «Методика навчання іноземних мов в НГУ». Харків, 2020. Національна академія Національної гвардії України. URL: https://nangu.edu.ua/uploads/files/documenty/osvita/sertyficaciya/kursy/Metodyka\%20navchannia\%20inozemnykh $\% 20 \mathrm{mov} \% 20 \mathrm{v} \% 20 \mathrm{NHU} . \mathrm{pdf}$

5. Медвідь М. Черніченоко І. Медвідь Ю. Дем'янішин В. Імплементація постанови КМУ від 21.08 .2019 р. № 800 «деякі питання підвищення кваліфікації...» в процесі становлення викладача-початківця вищого військового навчального закладу. Молодь і Ринок. 2020. № 6-11.

6. Медвідь Ю.І., Водчиць О.Г. Змістово-функціональна модель фрормування готовності майбутніх офріцерів запасу до службово-бойової діяльності в процесі професійної підготовки та результати її експерементальної перевірки. Педагогічні науки. 2018. Вип. 72. С. 103-123.

\section{References:}

1. STANAG 6001 (5th Edition) NATO Standardization Office. Brussels, 2014, 56 p.

2. Gonchar V. (2021) Vyznachennya sutnosti hotovnosti ofitseriv do zdiysnennya movnoyi pidhotovky u viys'kovykh chastynakh Natsional'noyi hvardiyi Ukrayiny [Determining the essence of the readiness of officers for language training in the military units of the National Guard of Ukraine]. Bulletin of Luhansk National University Taras Shevchenko, no. 1(339), part I, pp. 91-104. 
3. Matsegora Y., Prykhodko I., Vorobyova I., Gorelyshev S., Kazyanina N. (2013) Psykholohichnyy monitorynh profesiyno vazhlyvykh yakostey kursantiv VVNZ MVS Ukrayiny [Psychological monitoring of professionally important qualities of cadets of higher educational institutions of the Ministry of Internal Affairs of Ukraine]: monograph. Kharkiv: Acad. BB of the Ministry of Internal Affairs of Ukraine, $421 \mathrm{p}$.

4. Osvitn'o-profesiyna prohrama pidhotovky slukhachiv kursiv pislyadyplomnoyi osvity «Metodyka navchannya inozemnykh mov v NHU» (2020) [Educational and professional training program for students of postgraduate education courses "Methods of teaching foreign languages at NMU"]. Kharkiv. National Academy of the National Guard of Ukraine. URL: https://nangu.edu.ua/uploads/files/documenty/osvita/sertyficaciya/kursy/Metodyka\%20 navchannia\%20inozemnykh\%20mov\%20v\%20NHU.pdf

5. Medvid M., Chernichenoko I., Medvid Y., Demyanyshyn V. (2020) Implementatsiya postanovy KMU vid 21.08.2019 r. № 800 “deyaki pytannya pidvyshchennya kvalifikatsiyi...” v protsesi stanovlennya vykladachapochatkivtsya vyshchoho viys'kovoho navchal'noho zakladu [Implementation of the resolution of the CMU dated 21.08.2019 № 800 “some issues of advanced training...” in the process of becoming a beginning teacher of a higher military educational institution]. Youth and the Market, no. 6-11.

6. Medvid Y., Vodchyts O. (2018) Zmistovo-funktsional'na model' formuvannya hotovnosti maybutnikh ofitseriv zapasu do sluzhbovo-boyovoyi diyal'nosti v protsesi profesiynoyi pidhotovky ta rezul'taty yiyi eksperemental'noyi perevirky [Semantic and functional model of formation of readiness of future reserve officers for service and combat activity in the process of professional training and results of its experimental verification]. Pedagogical sciences, no. 72, pp. 103-123. 